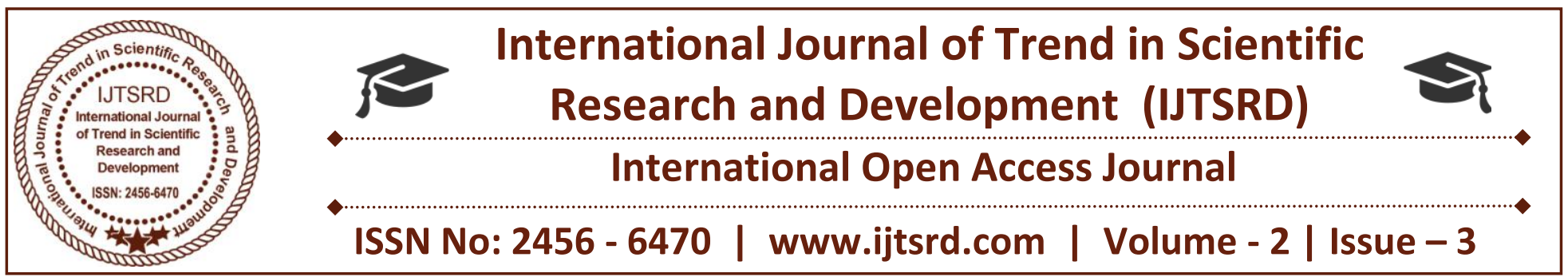

\title{
Effects of Aqueous Leaf Extract of Cashew (Anacardium Occidentale) on Paracetamol Induced Hepatotoxicity of Adult Male Wistar Rats
}

\begin{abstract}
Okonkwo, C. O. J
Department of Human Physiology, Faculty of Basic Medical Sciences, College of Medicine, Nnamdi Azikiwe University, Nnewi Campus, Okofia,
\end{abstract} Anambra State, Nigeria
Oguaka V.N.

Department of Human Biochemistry, Faculty of Basic Medical Sciences, College of Medicine, Nnamdi

Azikiwe University, Nnewi Campus, Okofia,

Edeh, A.I

Department of Human Physiology, Faculty of Basic Medical Sciences, College of Medicine, Nnamdi Azikiwe University, Nnewi Campus,

Okofia, Anambra State, Nigeria

\section{ABSTRACT}

While paracetamol is described as relatively nontoxic when administered in therapeutic doses, it is known to cause toxicity when taken in a single or repeated high dose, or after chronic ingestion. Adverse events typically associated with paracetamol intoxication include acute liver failure (ALF), centrilobular hepatic necrosis, renal tubular necrosis and hypoglycemic coma.

Cashew (Anacardium occidentale) has been used both as source of nutrition and medicinally worldwide.

A total of 25 adult male Wistar rats weighing $100 \mathrm{~g}$ $200 \mathrm{~g}$ were used for this study. The animals were divided into 5 groups of 5 rats each. $1000 \mathrm{mg} / \mathrm{kg} / \mathrm{body}$ weight of paracetamol was given for 3 days to induce liver damage in groups B-E. Group A served as the normal control group and received feed and water throughout the period of the experiment. Group B served as negative control group and received feeds and water throughout the period of the experiment, but no treatment with the extract. Group C, D and E received $150 \mathrm{mg}, 300 \mathrm{mg}$ and $500 \mathrm{mg} / \mathrm{kg}$ of the extract for 21 days.
All data obtained were subjected to statistical analysis using t-test, one-way ANOVA and POST HOC LSD using SPSS version 20. Differences between means were regarded significant at $\mathrm{P}<0.05$. Data were expressed as mean + standard error of mean (SEM).

The result showed a significant increase in AST in Group E $(\mathrm{P}<0.05)$ when compared to Group A. However, there was a decrease in Group $\mathrm{C}$ when compared to Group B. Also, there was a significant increase in ALT in Group D $(\mathrm{P}<0.05)$ and Group E $(\mathrm{P}<0.05)$, when compared to Group A. However, there was a decrease in Group C for both AST and ALT when compared to Group B.

From this study, it can be said that aqueous leaf extract of Anacardium occidentale has a little correction effect on Paracetamol induced hepatotoxicity in small doses. However, it can exert a serious toxic effect on the liver with increased dosage.

\subsection{BACKGROUND OF STUDY}

Paracetamol, also known as acetaminophen, is the most commonly used antipyretic and pain reliever and since 1955 has been available over-the-counter as a 
single formulation or in combination with other substances (Sheen et al, 2002). World Health Organization indicated that this drug can be used in all the three steps of pain intensity (WHO, 2013).

Being the main drug prescribed for feeble pains, it can be used together with non-steroidal analgesic drugs also to treat pains of moderate intensity. When pain persists or increases, paracetamol is used as an additional analgesic in combination with weak (e.g. tramadol) or strong (e.g., morphine, fentanyl) opioids (WHO, 2013).

While paracetamol is described as relatively nontoxic in therapeutic doses, it can be toxic when taken in a single or repeated high dose, or after chronic ingestion. Adverse effects typically associated with paracetamol intoxication are include acute liver failure, renal tubular necrosis and hypoglycemic coma (De Giorgio et al, 2013, Lancaster et al, 2015). According to recent information provided by the American National Poison Data System (NPDS), paracetamol is one of the 25 drugs associated with the largest number of fatalities, either alone or in combination with other medications (Mowry et al, 2015). Several paracetamol overdoses are closely related to suicide attempts, but also unintentional or cumulative overdosing can occur, usually caused by a misuse of the drug, even when therapeutic doses are administered. Many cases of paracetamol poisoning are also due to the use of paracetamol combination products such as codeine, oxycodone and caffeine (Doyon et al, 2013). Other factors can also contribute to this hepatotoxicity even at therapeutic dose and include alcohol abuse, malnutrition, underlying or pre-existing liver disorders and concomitant ingestion of other potentially hepatotoxic drugs (Karwoski, 2012).

Cashew (Anacardium occidentale) has been used both as source of nutrition and medicinally worldwide. The bark, leaves and shell oil of the plant are used to treat different ailments (Agedah et al., 2010). Leaf extract of Anacardium occidentale possess phyto-constituents such as saponins, tannins, and flavonoids, which have been reported to exert antioxidant activities (Gonçalves et al, 2005, Jaiswal et al, 2010). The antimicrobial activity of the cashew leaf extract has been documented by several researchers (Omojasola and Awe, 2004; Agedah et al., 2010; Ifesan et al., 2013), where the anti-bacterial, anti-fungal, anti-protozoan, antihelminthic and anti-viral activities of various part extract of cashew were recorded. It has also been reported to possess anti-diabetic, anti-inflammatory activity (Mendes et al, 1990) and anti-ulcerogenic properties (Akinpelu, 2001).

\subsection{STATEMENT OF PROBLEM}

Some of the liver injuries are caused by the use and abuse of drugs. Conventional and/or synthetic drugs such as steroids, vaccines, antivirals and other medications can cause serious side effects, even toxic effects on the liver, especially when used for prolonged periods of time. Paracetamol, a widely used over-the-counter analgesic and antipyretic, is one of the best known experimental models of hepatotoxicity. It is safe at therapeutic doses but causes a fatal hepatic necrosis and hepatic failure in overdose.

\subsection{AIM}

The aim of the study is to evaluate the effect of aqueous leaf extract of cashew (anacardium occidentale) on paracetamol induced hepatotoxicity.

\subsection{SPECIFIC OBJECTIVES}

1. To determine the level of liver enzymes Aspartate aminotransferase and Alanine aminotransferase with and without cashew leaf extract

2. To ascertain if the aqueous extract of cashew leaves (anacardium occidentale) has toxic effects or remedial effect on paracetamol induced hepatotoxicity

\subsection{SIGNIFICANCE OF THE STUDY}

Works have been done on the extract of cashew leaf (anacardium occidentale) and its ameliorating effects on different diseases in the body.

The extracts are used to treat malaria (Razalia et al., 2008; Orwa et al., 2009). Franca et al (1996) reported that the leaf extract (tannin) of cashew is used in the treatment of bronchitis. Pawar and Pal (2002) and Ojewole (2004) reported the anti-inflammatory effect of cashew leaf extract, as shown in carrageenan induced rat paw edema. Anacardium occidentale also has antimicrobial (Laurens, 1999), hypoglycaemic and antidiabetic (Kamtchouing et al., 1998; Ojewole, 2004; Tedong, 2006) and molluscicide (Mendes et al., 1990) activities.

However, no work has been documented on the effect of this extract on remedying paracetamol induced hepatotoxicity. 


\subsection{SCOPE OF STUDY}

The scope of this study is limited to the induction of liver damage with paracetamol, the administration of aqueous leaf extract of anacardium occidentale and the estimation of the liver enzymes Alanine transaminase and Aspartate transaminase to ascertain the effects of the extract.

\subsection{BOTANICAL BACKGROUND}

Although plants have been used for food, building materials and fuel purposes, it has also been used as medicine. In developing countries, most of the people depend on herbal medical care (Ekpe et al, 1990). Although, poisonous plants are ubiquitous, herbal medicine is used by up to $80 \%$ of the population in the developing countries

(Jaouad et al., 2004). In spite of tremendous scientific advancement in the field of hepatology in recent years, liver problems are on the rise; (Perz et al, 2006) high mortality and morbidity, its medical management is still inadequate as conventional or synthetic drugs used in the treatment of liver diseases are inadequate and sometimes can have serious side effects (Prakash et al, 2008). According to Biswas et al, 2010, medicinal plants are being increasingly utilized to treat a wide variety of diseases, and are promising natural source of hepatoprotective and antioxidant compounds valuable in the treatment of liver disorder and in the protection against poisoning from chemical and environmental toxins. Phytochemicals found in many medicinal plants, phenolic compounds such as flavonoids and isoflavonoids have been proved to play an important role in the treatment of many diseases (Soufy, 2012). Hence, people, including those in developed countries, are looking at the traditional systems of medicine for remedies to hepatic disorders (Prakash et al, 2008).

Anacardium occidentale (extracts from roots, stems and fruits) has been in use as a folk remedy for some diseases, for example, diabetes mellitus (Kamtchouing et al, 1998, Sokeng et al, 2001).

A phytochemical screening analysis on Anacardium occidentale leaves has showed the presence of high concentration of tannins in the aqueous extract of the leaf (Abulude et al., 2010). This could probably account for the effective action of the aqueous form compared to the methanolic extract in the inhibitory activity against $P$. gingivalis and $P$. intermedia (Varghese et al., 2013). These are infections that are commonly spread by sex, especially in vaginal intercourse, anal sex and oral sex (Patrick et al., 2013). Microorganisms involved include bacteria and viruses. Akash et al. (2009) reported that the leaves of cashew are useful in the treatment, since extract of cashew leaves had been reported for their antimicrobial activities.

In the traditional Nigerian and Brazilian pharmacopoeia, stem bark of Anacardium occidentale is known for its anti-inflammatory effects (Mota et al, 1985, Chen \& Chung, 2000, Ojewole, 2003).

Dare et al (2011) carried out a research on the effects of the aqueous extract of Anacardium occidentale leaf on the pregnancy outcome of female Wistar rats. From observations made, there was no difference in behavioral changes noticed between the control group and experimental groups. There was no mortality, treatment-related signs of maternal toxicity, stress or abnormal behavioral changes observed within the experimental groups throughout the gestation period. The body weight of the pregnant rats in control and experimental groups, measured on the first, eighth and fifteenth day of pregnancy shows variations. However, Gestation periods of the experimental rats were observed longer than the control which is normally 21 days. The pups born to rats/dams treated with the leaf extract had low mean birth weight and less crown-rump length in the experimental groups compared to the control group. Therefore, they concluded that consumption of the leaf extract during pregnancy have serious implications.

Ikyembe et al (2014) carried out a research on the hepatoprotective effect of methanolic leaf extract of Anacardium occidentale on carbon tetrachlorideinduced liver toxicity in Wistar rats. Their result was in accordance with studies related to $\mathrm{CCl} 4$-induced hepatotoxicity. The Methanolic Leaf extract of Anacardium occidentale was effective, histologically and biochemically, in preventing CCl4-induced acute liver injury in Wistar rats, especially at dose of 500 $\mathrm{mg} / \mathrm{kg}$. The hepatoprotective activity of the plant extract, which could be of therapeutic potentials, may be consequent to the antioxidant activities of constituent phytochemicals. Hepatoprotective effect was studied by histological and serum marker enzymes analysis. Methanolic Leaf extract of Anacardium occidentale showed significant $(\mathrm{P}<$ 0.05) hepatoprotective effect by lowering the levels serum liver enzymes: AST, ALT, and ALP, which were in turn confirmed by histopathological 
examinations of liver sections and are comparable with the reference drug.

Anacardium occidentale fruit is a rich source of vitamins, minerals, and other essential nutrients. According to Dare et al, (2011), it has up to five times vitamin $\mathrm{C}$ than oranges and contains a high amount of mineral salts. Leaves extract of Anacardium occidentale possess phyto-constituents such as saponins, tannins, and flavonoids, which have been reported to exert antioxidant activities (Gonçalves et al, 2005, Jaiswal et al, 2010); a strong antioxidant capacity was also observed against hepatocarcinogenesis induced by aflatoxin B1 in Wistar mice (Premalatha \& Sachdanandam, 1999).

Olaniyan, (2016) carried out a research on the cholesterol lowering effect of cashew leaf extract on egg yolk induced hypercholesterolaemic rabbits. The leaf ethanolic extracts presented a higher activity than the aqueous extracts. The work was designed to determine the Cholesterol Lowering Effect of Cashew leaf (Anacardium occidentale) extract. A significant decrease was also obtained in plasma Total cholesterol and Total triglycerides in the rabbits given $400 \mathrm{mg} / \mathrm{Kg}$ of either methanolic or aqueous extract of cashew leaves extract after they were being given $20 \%$ of powdered egg yolk of the total meal weight plus water for seven days which was more in ethanolic extract than the aqueous extract. There was also a significantly lower Low Density Lipoprotein-C in rabbits fed with normal meal containing $20 \%$ of powdered egg yolk of the total meal weight plus water for seven days followed by the administration of $400 \mathrm{mg} / \mathrm{Kg}$ of ethanolic extract for another seven days. than when the rabbits were fed with normal meal containing $20 \%$ of powdered egg yolk of the total meal weight with water for seven days and also than in the rabbits induced with hypercholesterolemia using $20 \%$ of powdered egg yolk of the total meal weight followed by aqueous cashew leaf extract. Cholesterol lowering effect of the leaf extract could be linked with the antioxidant phytoconstituents of the leaf.

Sambo et al, (2014) carried out an experiment on the antidiabetic activity of aqueous extract of Anacardium occidentale stem bark in normal and alloxan induced diabetic rats. Alloxan-induced diabetic and nondiabetic rats were administered orally with aqueous extract of Anacardium occidentale stem bark at 400 $\mathrm{mg} / \mathrm{kg}$ for 28 days, after which the blood glucose, total protein, albumin, marker enzymes, lipid profile and some haematological indices were determined and compared with the normal control. There was a significant $(\mathrm{p}<0.05)$ increase in the level of blood glucose, alanine transaminase (ALT), aspartate transaminase (AST), alkaline phosphatase (ALP), total cholesterol, low density lipoprotein, triglyceride and a significant $(\mathrm{p}<0.05)$ decrease in the level of high density lipoprotein, total protein, albumin, packed cell volume, haemoglobin, red blood cell and white blood cell of the diabetic untreated rats. Oral administration of aqueous extract of Anacardium occidentale stem bark at a dose of $400 \mathrm{mg} / \mathrm{kg}$ body weight for 28 days to diabetic rats resulted in a reversal of the above diabetic conditions.

\subsection{TAXANOMY OF ANACARDIUM OCCIDENTALE}

Kingdom: Plantae

Division: Magnoliophyta

Class: Magnoliospsida

Order: Sapindales

Family: Anacardiaceae

Genus: Anacardium

Species: occidentale

Botanical name: Anacardium occidentale (Omoboyowa, 2011).

\section{COMMON NAMES}

Local Names: Cashew has different names in different language groups in Nigeria, namely Kashu (Hausa); Kashuu (Igbo); Kaju (Yoruba) (Orwa et al., 2009).

\subsection{PLANT DESCRIPTION}

Anacardium occidentale is a tree in the family of the flowering plant Anacardiaceae. The family contains 73 genera and about 600 species. It is a multipurpose tree of the Amazon that grows up to $15 \mathrm{~m}$ high. It has a thick and tortuous trunk with branches so winding that they frequently reach the ground (Morton, 1987). Its leaves are simple, spirally arranged, leathery textured, elliptic to ovate, 4 to $22 \mathrm{~cm}$ long and 2 to 15 $\mathrm{cm}$ broad, with a smooth margin, alternate, glabrous, round at ends, $10-18 \times 8-15 \mathrm{~cm}$ with short petiole (Orwa et al., 2009). The cashew tree produces many resources and products. The nut which is the true fruit dries and does not split open. Inside the poisonous 
shell is a large curved seed, which is the edible cashew kernel. As the nut matures, the stalk (receptacle) at the base enlarges rapidly within a few days into the fleshy fruitlike structure, broadest at the apex, known as the fruit (Orwa et al., 2009). The cashew nut has international appeal and market value as food. The pseudo-fruit, a large pulpy and juicy part, have a fine sweet flavor and are commonly referred to as the "cashew fruit" or the "cashew apple" (Dare et al, 2011).

Figure 2.1: Fresh cashew leaves (Omoboyowa, 2011)

\subsection{CULTIVATION AND GEOGRAPHICAL DISTRIBUTION}

In 1970s, Africa was the largest producer of cashew nuts accounting for $67.5 \%$ of world production. This subsequently declined to $35.6 \%$ by 2000 , with Nigeria, Tanzania and Mozambique being largest producers. The production in Asia during the same periods increased from $26.8 \%$ to $49.5 \%$ with the major producer being India, Indonesia and Vietnam (Hammed et al, 2008).

As in the case of other developing countries, Nigeria has recognized the potential economic value of cashew and has made a concerted effort to improve production of the crop. During the last five to ten years, Nigeria has emerged as a largest producer of cashew nuts in Africa (Ogunsina and Lucas, 2008)

\subsection{PHYTOCHEMICAL CONSTITUENTS OF ANACARDIUM OCCIDENTALE}

Alkaloids, Flavonoids (Konan and Bacchi, 2007). Phenolic acids (Ajileye et al., 2015). From the leaf shoots of two varieties of Anacardium occidentale, 15 flavonol glycosides have been identified by Shukri and Alan (2010). Overall, the total phenolic content of leaf shoots of the red variety was almost two times that of the yellow variety.

According to Andarwulan et al. (2012), quercetin $(125 \mathrm{mg} / 100 \mathrm{~g})$ is the dominant flavonoid and chlorogenic acid $(13.5 \mathrm{mg} / 100 \mathrm{~g})$ is the dominant phenolic acid in cashew leaves. Other phenolic compounds reported in the leaves include anthocyanidins of cyanidin and peonidin (Kongkachuichai et al, 2015). The leaf oil contains (E)- $\beta$-ocimene $(29 \%), \alpha$-copaene $(14 \%)$ and $\delta$ cadinene $(9 \%)$, the fruit oil contains palmitic acid (20\%) and oleic acid (20\%), and the flower oil contains $\beta$-caryophyllene (26\%), methyl salicylate
(13\%) and benzyl tiglate (11\%) as major components (Maia et al., 2000).

\subsection{THERAPEUTIC USES OF ANACARDIUM OCCIDENTALE}

\subsubsection{ANTIOXIDANT AND NITRIC OXIDE INHIBITION ACTIVITIES}

Reactive oxygen species (ROS) possess a strong oxidizing effect and induce damage to biological molecules including proteins and DNA with concomitant changes in their structure and function.

The methanolic and aqueous leaf extracts of Anacardium occidentale have been reported to possess the ability to act as an antioxidant in vitro and in vivo; these were also able to increase the level of superoxide dismutase and catalase in experimental hypercholesterolemia (Fazali et al, 2011). Flavonoids are potent water-soluble antioxidants and free radical scavengers which prevent oxidative cell damage (Del et al., 2005; Okwu, 2004). Ascorbic acid is another component of the extract and it is an effective scavenger of superoxide radical anion, hydroxyl radical, single oxygen and reactive nitrogen oxide (Weber et al, 1996).

Antioxidant activity of the hydroalcoholic extracts of cashew leaves was evaluated by measuring the production of hydroperoxide and its degradation product (malonaldehyde) resulting from linoleic acid oxidation using ferric thiocyanate and thiobarbituric acid methods, respectively. Griess assay was used to assess NO-inhibitory activity of the extracts (Abas, 2006).

\subsubsection{ANTIBACTERIAL AND ANTIVIRAL PROPERTIES}

When tested against Gram-positive bacteria of Brevibacillus brevis, Micrococcus luteus and Staphylococcus cohnii, and Gram-negative bacteria of Escherichia coli, Pseudomonas aeruginosa and Salmonella enterica using the disc-diffusion method, leaves of Anacardium occidentale inhibited all bacterial species except S. enterica (Tan and Chan, 2014). Minimum inhibitory dose ranged from 0.13-0.50 mg/disc. Against E. coli, P. aeruginosa, Bacillus cereus, Bacillus megaterium and Cryptococcus neoformans, cashew leaves inhibited all 
bacterial species except E. coli (Mackeen et al., 1997). Other studies by Anand et al, 2015 and Thomas et al, 2015 also reported on the antibacterial properties of Anacardium occidentale leaves. Inhibition of the leaf extract of Anacardium occidentale was stronger than that of the bark extract (Manasa et al., 2013) while the flower extract displayed the strongest inhibition (da Silva et al., 2016). The essential oil extracted from leaf shoots of cashew also possessed antimicrobial activity (Nor Ayshah Alia et al., 2016). Among 12 medicinal plant species screened for simian (SA-11) and human (HCR3) rotavirus inhibition in Brazil, the aqueous leaf extract of Anacardium occidentale inhibited the growth of SA-11 by $85 \%$ at non-cytotoxic concentration of $4.0 \mu \mathrm{g} / \mathrm{ml}$ (Gonçalves et al., 2005).

\subsubsection{ANTIFUNGAL PROPERTIES}

Cashew leaves have been shown to have antifungal activity based on a study conducted on the microbiology of dentures of 50 elderly people from Mangalore in Karnataka, India (Shetty et al., 2014). Results showed that cashew leaves can be used as a natural cleansing agent although their antifungal activity was not as effective as denture cleansing tablets of Triphala.

\subsubsection{CHOLESTEROL LOWERING EFFECT}

Cholesterol lowering effect of the leaf extract could be linked with the antioxidant phyto-constituents of the leaf. Reactive oxygen species are forms of oxygen that has been chemically modified into a highly unstable substance. These free radicals are unstable because they are missing electrons, which must be replaced. If the compound giving up its electrons is the fat and protein in an LDL-cholesterol molecule, the result is the formation of fatty lesions in the walls of the blood vessels (Abiaka et al, 2001).

\subsubsection{HYPOGLYCAEMIC PROPERTIES}

Results indicated that cashew leaves have a protective effect against STZ-induced diabetes in rats (Kamtchouing et al., 1998). A related study reported that oral administration of the methanol leaf extract of Anacardium occidentale at doses of 35, 175 and 250 $\mathrm{mg} / \mathrm{kg}$ significantly reduced blood glucose levels in diabetic rats after 3 hours (Sokeng et al., 2007). When administered repeatedly with $175 \mathrm{mg} / \mathrm{kg}$ of extract, the decline in blood glucose (48\%) was more pronounced. The hexane leaf extract of cashew (300 $\mathrm{mg} / \mathrm{kg}$ ) had no nephrotoxic effect in normal rats, and effectively reduced diabetes-induced functional and histological alterations in the kidney (Tedong et al., 2006). The leaf extract of Anacardium occidentale has been reported to significantly lower blood glucose levels in normoglycaemic and hyperglycaemic rabbits (Esimone et al., 2001), in normoglycaemic rats (Saidu et al., 2012), and in alloxan-induced diabetic rats (Fagbohun and Odufuwa, 2010).

\subsubsection{ANTIULCEROGENIC ACTIVITY The} antiulcerogenic effect of a hydroethanolic leaf extract of Anacardium occidentale was investigated by Konan and Bacchi in 2007. The extract inhibited gastric lesions induced by $\mathrm{HCl} /$ ethanol in female rats. A dose-response effect study showed that the ED50 was $150 \mathrm{mg} / \mathrm{kg}$ of body weight. Extract doses higher than $100 \mathrm{mg} / \mathrm{kg}$ of body weight were more effective than $30 \mathrm{mg} / \mathrm{kg}$ of lansoprazol in inhibiting gastric lesions. A methanolic fraction $(257.12 \mathrm{mg} / \mathrm{kg})$ which reduced gastric lesion at $88.20 \%$ is likely to contain the active principle of the antiulcer effect (Konan \& Bacchi, 2007).

\subsubsection{ANALGESIC INFLAMMATORY \\ AND ANTI-}

Leaves extracted with petroleum ether, chloroform and methanol were screened for analgesic and antiinflammatory activity using the carrageenan-induced rat paw edema assay by Pawar et al (2000). Results showed that the petroleum ether and chloroform leaf extracts, and the acetone soluble fraction of the methanol extract exhibited $57 \%, 48 \%$ and $62 \%$ inhibition of paw oedema, respectively. The aqueous, hexane, dichloromethane and methanol leaf extracts of Anacardium occidentale were investigated for analgesic effects on acetic acid-induced pain in mice showed that the extracts significantly reduced the number of writhing and the highest analgesic effect was seen in the dichloromethane extract (Onasanwo et al., 2012 \& 2013).

\subsubsection{ANTI-HYPERTENSIVE ACTIVITY}

A purified Anacardium occidentale leaf extract has shown to have in vitro anti-hypertensive effects using the isolated organ technique (Nugroho et al., 2013). At 0.5 and $1.0 \mathrm{mg} / \mathrm{ml}$, the extract reduced the contraction of isolated rat aorta induced by phenylephrine by $26 \%$ and $40 \%$, respectively. This finding was complemented by reports that the aglycones and glycosides of quercetin (major constituents of cashew leaves) have the ability to reduce hypertension (Duarte et al., 2001), to stimulate 
vasorelaxation of aortic vessels (Khoo et al., 2010), and to lower blood pressure (Larson et al., 2012) in animal models and human subjects.

\subsection{PARACETAMOL}

Paracetamol or acetaminophen was discovered in Germany at the end of the $19^{\text {th }}$ century. It is known to probably be the most versatile and widely used analgesic and antipyretic drug worldwide (Rocha et $a l, 2005)$.

\subsubsection{ROUTES OF ADMINISTRATION}

The routes of administration for paracetamol include oral, rectal and intravenous routes (Hochhauser, 2014). The half-life of paracetamol according to a research by Lewis and Stine in 2013 was estimated to be about 1 to 4 hours after administration.

\section{$\begin{array}{lllll}\text { 2.7.2 ORIGIN AND HISTORY OF } & \text { H }\end{array}$ PARACETAMOL}

Paracetamol was discovered in 1977. It is the most commonly used medication for pain and fever worldwide (WHO, 2013). Paracetamol $@$ was first marketed in the united states in 1950 under the name Triagesic, a combination of paracetamol, aspirin and caffeine. It is part of the class of drugs known as "aniline analgesics" and is the only such drug still in use today.

In some contexts, such as on prescription bottles of painkillers that incorporate this medicine, it is simply abbreviated as APAP, for acetyl-para-aminophenol or acetaminophenol. Both acetaminophenol and paracetamol come from a chemical name for the compound para-acetylaminophenol and paraacetylaminophen

\subsubsection{MEDICAL USES OF PARACETAMOL PAIN}

According to Perrot et al, (2004), paracetamol is used for the relief of mild to moderate pain. However, the use of the intravenous form for pain of sudden onset in people in the emergency department is supported by limited evidence.

\section{FEVER}

Paracetamol is used for reducing fever in people of all ages. The world Health Organization recommends that paracetamol be used to treat fever in children only if their temperature is greater than $38.5{ }^{\circ} \mathrm{C}$. the efficacy of paracetamol by itself in children with fevers has been questioned and a meta-analysis showed that it is less effective than ibuprofen (Perrot et al, 2004).

\section{HEADACHES}

A joint statement of the German, Austrian and Swiss headache societies and the German society of neurology recommends the use of paracetamol in combination with caffeine as one of the several first line therapies for treatment of tension or migraine headache. In the treatment of acute migraine, it is superior to placebo with $39 \%$ of people experiencing pain relief at 1 hour compared to $20 \%$ in the control group (Derry and Moore, 2013).

\subsubsection{DRUG INTERACTION}

The efficacy of paracetamol when used in combination with weak opioids such as codeine improved for approximately $50 \%$ of people but with increases in the number experiencing side effects. Combinations of paracetamol and strong opioids like morphine improve analgesic effect. Its combination with caffeine is superior to paracetamol alone for the treatment of common pain conditions including dental pain, postpartum pain and headache (Derry and Moore, 2013).

\subsubsection{PHARMACOKINETICS PARACETAMOL}

OF

After administration through the oral route, absorption occurs rapidly in the duodenum (McGill \& Jaeschke, 2013). If a patient consumes food around the same time of Paracetamol ingestion, there may be a delay in the time of, but not the extent of, drug absorption (McGill \& Jaeschke, 2013). Much like concurrent food consumption causing time-delay in Paracetamol absorption, a patient with chronic liver disease is at risk of prolonged drug serum half-life (by an average of 2.0 to 2.5 hours, and up to more than 4 hours), especially if extended-release Paracetamol formulations are consumed. While an overdose of Paracetamol yields peak serum concentrations (10 $20 \mathrm{mg} / \mathrm{mL}$ ) within 4 hours, a patient taking the medication safely will achieve peak concentrations within 1.5 hours, with a half-life of $1.5-3$ hours.

It is primarily metabolized in the liver into toxic and nontoxic products. The majority $(90 \%)$ of the Paracetamol is funneled into phase II metabolic pathways, in which Paracetamol conjugation is 
catalyzed by UDP-glucuronosyl transferases and sulfotransferase, with conversion to glucuronidated and sulfated metabolites that are eliminated from the body in the urine. A small, measurable amount of Paracetamol $(2 \%)$ is excreted in the urine without having undergone any metabolism (McGill \& Jaeschke, 2013). Another portion of Paracetamol $(10 \%)$ is shunted by hepatic cytochrome CYP 2E1 (to a lesser extent with CYP $1 \mathrm{~A} 2$ and 3A4) to phase I oxidation, in which a highly reactive toxic metabolite, $\mathrm{N}$-acetyl-para-benzo-quinone imine (NAPQI), is formed (Jaeschke \& McGill, 2012, 2015). Phase III involves metabolite transport in the form of biliary excretion that requires transporters (McGill \& Jaeschke, 2013). In non-toxic ingestion of Paracetamol, the processing of NAPQI occurs with rapid conjugation by hepatic GSH to form nontoxic mercaptate and cysteine compounds that are excreted in urine (McGill \& Jaeschke, 2012). Myeloperoxidase and cyclooxygenase- 1 are enzymes that also function in the processing of NAPQI into non-reactive metabolites.

\subsubsection{PARACETAMOL HEPATOTOXICITY AND LIVER DAMAGE}

Paracetamol is reported to be regularly consumed by over 60 million Americans on a weekly basis, making it the most widely utilized analgesic and antipyretic (Herndon \& Dankenbring, 2014). Advertised as safe in doses up to $4000 \mathrm{mg}$ every 24 hours by the United States Food and Drug Administration (FDA), consumption at this dose generally does not yield any toxic effects (Herndon \& Dankenbring, 2014). As such, it may be difficult to recognize Paracetamol toxicity, partly due to its availability in various formulations, such as tablets, liquids, rectal suppositories and intravenous liquids, as well as in combination supplements sold as over-the-counter and prescription products for analgesia (Herndon \& Dankenbring, 2014).

Paracetamol hepatotoxicity occurs through formation of the noxious NAPQI metabolite, which is present in excessive quantities, as augmented by features of glutathione (GSH) depletion, oxidative stress and mitochondrial dysfunction leading to depletion in adenosine triphosphate (ATP) stores (Jaeschke \& McGill, 2012, 2015). There is evidence to support the theory that the metabolic activation of Paracetamol generates NAPQI that binds to a number of cellular proteins, especially mitochondrial proteins. Adherence to mitochondrial proteins, especially in the setting of GSH depletion, is important because mitochondrial protein binding depletes native antioxidant functions and also alters the mitochondrial ATP-synthase a-subunit, leading to ineffective ATP production (Jaeschke \& McGill, 2012, 2015). Mitochondria, which are critical for cellular respiration and metabolism, suffer damage to their own mitochondrial DNA by the actions of reactive oxygen species and peroxynitrite compounds, and they have been directly implicated in the process leading to cessation of ATP synthesis (Jaeschke \& McGill, 2012). Untreated paracetamol overdose results in a lengthy, painful illness. Signs and symptoms usually begin several hours after ingestion, with nausea, vomiting, sweating and pain as acute liver failure starts (Fortuny et al, 2006).

\subsubsection{FACTORS PARACETAMOL-RELATED HEPATOTOXICITY}

The most essential factor in both the development and severity of Paracetamol hepatotoxicity is the ingested dose, but some argue that the length of time from Paracetamol ingestion to $\mathrm{N}$-acetylcysteine (NAC) therapy ("time to NAC") is equally if not more important (Liu, Govindarajan \& Kaplowitz, 2004, Schmidt, Dalhoff \& Poulsen, 2006). Liver metabolism during glucouronidation or sulfation, CYP activity and maintenance of hepatic GSH supply depends on patient factors such as age, nutritional status, preexisting liver disease, concurrent use of alcohol and other liver-metabolized medications, genetic predispositions, and most importantly, the acuity or chronicity of Paracetamol overuse (Schmidt, Dalhoff \& Poulsen, 2006).

\subsection{THE LIVER}

The liver is the largest glandular and one of the vital organs of the body (Abdel-Misih et al, 2010). Anatomically, it lies in the right hand side of the abdominal cavity below the diaphragm to the right of the stomach and overlies the gallbladder. The liver has wide range of physiological roles including metabolism, decomposition of red blood cells, synthesis of serum proteins and detoxification, the liver also produces bile, an enzyme that aids in digestion by emulsifying lipids (Tortora et al, 2008).

\subsubsection{STRUCTURE OF THE LIVER}

The liver is the heaviest internal organ in the body. It is a wedge-shaped organ, reddish brown in color, 
made up of 4 lobes of unequal size and shapes. The lobes include the right, left, caudate and quadrate lobes. The surfaces of the liver have several impressions, which include the colic impression, renal impression, suprarenal impression, duodenal impression and gastric impression. The liver of a normal human being weighs $1.44-1.66 \mathrm{~kg}$. The liver is supplied with nutrient rich blood from the spleen, pancreas, stomach, the small and large intestines. It also receives oxygenated blood from the aorta. Blood enters through the small portal, hepatic artery and the bile duct, where it is mixed before flowing past the hepatocytes towards the central vein. The liver sinusoids connect the central vein and the triad vessels. The bile canaliculus is a channel formed by adjacent hepatocytes to drain bile to the bile ducts. The canal of Herring forms the connection between the bile canaliculi and the bile ducts (Cotran et al, 2005).

The liver is made up of hepatocytes which are parenchymal cells comprising 70-80 percent of the liver mass. These cells play a role in the metabolism of carbohydrates and protein, detoxification and the formation and secretion of bile. These cells have the ability to regenerate. Stellate cells, macrophages, endothelial cells, fibroblasts and leucocytes (Pocock et al, 2006).

\subsubsection{FUNCTIONS OF THE LIVER}

The liver is considered the body's major biochemical factory. As part of the biliary system, together with the gallbladder and the associated ducts, its importance to the digestive system is its secretion of bile salts, which aid fats digestion and absorption. The liver plays an important role in the metabolic processing of the major categories of nutrients after their absorption from the digestive tract. These nutrients include carbohydrates, proteins and lipids (Sherwood, $7^{\text {th }}$ ed.)

The liver also helps in the detoxification or degrading of body wasted and hormones, as well as drugs and other foreign compounds. It also has a major part in the excretion of cholesterol and bilirubin, which is a breakdown product derived from the destruction of worn-out red blood cells. The ability of the liver to remove bacteria and worn-out red blood cells is due to its resident macrophages (Sherwood, $7^{\text {th }}$ ed.)

The steroid and thyroid hormones and cholesterol liver synthesizes plasma proteins, which include those needed for the clotting of blood, those that transport in the blood. And also angiotensinogen, important in the salt-conserving renin-angiotensin-aldosterone system. It also has a function in the secretion of the hormones thrombopoietin which stimulates platelets production, hepcidin, which inhibits iron uptake from the intestine, and insulin-like growth Factor-I, which stimulates growth. It also produces acute phase proteins important in inflammation (Jelkmann, 2001).

The liver aids in the activation of vitamin $\mathrm{D}$, in conjunction with the kidney. It also stores glycogen, fats, iron, copper and many other vitamins. The only liver function not accomplished by the hepatocytes is the phagocytic activity carried out by the resident macrophages, which are known as Kupffer cells (Sherwood, $7^{\text {th }}$ ed.).

\subsubsection{DISEASES OF THE LIVER}

The liver is prone to many diseases because of its strategic location and multidimensional functions. Liver diseases can be autoimmune or caused by excessive alcohol consumption resulting to alcoholic liver diseases and these include alcoholic hepatitis, fatty liver and cirrhosis. Liver damage can also be caused by drugs, which include paracetamol (Skandalakis et al, 2009). Some of the diseases of the liver include:

\section{Fatty liver}

This condition is also known as steatosis (the accumulation of fats in the liver cells). This can be idiopathic or caused by other factors. Alcohol causes development of large fatty globules throughout the liver and can begin to occur after few years of heavy drinking. There are other causes, collectively termed Non Alcoholic Fatty Liver Diseases. NAFLD begins with liver lipid accumulation and marked hepatic fat accumulation is a risk factor for disease progression. The progression of the disease is more likely in the setting of diabetes, insulin resistance and other preexisting conditions and it has been established that up to 80 percent of obese people have the disease (Sanyal, AJ 2002). The extreme form of NAFLD is Non-alcoholic steatohepatitis (NASH), and is the major cause of liver cirrhosis (Clark JM, Diehl AM, 2003).

\section{Hepatitis}

This is a condition characterized by inflammation of the liver. The most common cause is viral and they include hepatitis A, B, C, D and E. Some of these 
infections are sexually transmitted and hepatitis B and $\mathrm{C}$ viruses are the main causes of liver cancer.

\section{Alcohol liver diseases}

80 percent of ingested alcohol passes through the liver for detoxification. Chronic alcohol consumption results in the secretion of pro-inflammatory cytokines which are TNFalpha, Interleukin 6 and interleukin 8, oxidative stress, lipid peroxidation and acetaldehyde toxicity. These factors cause inflammation, apoptosis and eventually, fibrosis of the liver. It can also lead to fatty liver.

\subsubsection{LIVER REGENERATION}

The liver according to Haussinger et al, 2011, is the only internal organ in human beings, capable of natural regeneration of lost tissue. This is however not a true regeneration but rather a compensatory growth in mammals, otherwise known for restoration of function, not growing back to the original form. This is in contrast with true regeneration such as seen in fishes, where both original function and form are restored, restoring both the shape and size of the organ (Chu et al, 2009).

\subsubsection{ENZYMES HEPATOCELLULAR AMINOTRANSFERASES}

\section{THAT DETECT NECROSIS PSP-}

The aminotransferases (formerly transaminases) are the most frequently utilized and specific indicators of hepatocellular necrosis. These enzymes-aspartate Aminotransferase and alanine amino transferase catalyze the transfer of the $\alpha$-amino acids of aspartate and alanine respectively to the $\alpha$-keto group of ketoglutaric acid. Alanine aminotransferase is primarily localized to the liver but aspartate aminotransferase is present in the heart, skeletal muscle, kidney, brain and liver (Friedman et al, 2003). In acute liver damage, Aspartate aminotransferase is raised. Elevated Aspartate transaminase levels are not specific for liver damage, because Aspartate transaminase has also been used as a cardiac marker. The normal range of Aspartate transaminase is 6-40IU/L (Nyblom et al, 2006).

AST: alanine + a ketoglutarate $=$ oxaloacetate + glutamate

ALT: alanine + a ketoglutarate $=$ pyruvate + glutamate (Rosalki and Mcintyre, 1999).
Whereas aspartate Aminotransferase is present in both the mitochondria and cytosol of hepatocytes, Alanine aminotransferase is localized to the cytosol (Sherlock, 1997). The cytosolic and mitochondrial forms of aspartate aminotransferase are true isoenzymes and immunologically distinct (Green and Flamm, 2002). About $80 \%$ of AST activity in human liver is contributed by the mitochondrial isoenzyme, whereas most of the circulating AST activity in normal people is derived from the cytosolic isoenzyme (Boyde and Latner, 1961). Large increases in mitochondrial AST occur in serum after extensive tissue necrosis. Because of this, assay of mitochondrial AST has been advocated in myocardial infarction. Mitochondrial AST is also increased in chronic liver disease (Nalpus et $a l, 1986)$. Their activity in serum at any moment reflects the relative rate at which they enter and leave circulation. Of the numerous methods used for measuring their levels, the most specific method couples the formation of pyruvate and oxaloacetatethe products of the aminotransferase reactions to their enzymatic reduction to lactate and malate (Rej, 1985).

\section{MILD,MODERATE AND SEVERE}

\section{ELEVATIONS OF AMINOTRANSFERASES}

1. Severe (> 20 times, 1000 U/L): The AST and ALT levels are increased to some extent in almost all liver diseases. The highest elevations occur in severe viral hepatitis, drug or toxin induced hepatic necrosis and circulatory shock. Although enzyme levels may reflect the extent of hepatocellular necrosis they do not correlate with eventual outcome. In fact, declining AST and ALT may indicate either recovery of poor prognosis in fulminant hepatic failure (Friedman et al, 2003).

2. Moderate (3-20 times): The AST and ALT are moderately elevated in acute hepatitis, neonatal hepatitis, chronic hepatitis, autoimmune hepatitis, drug induced hepatitis, alcoholic hepatitis and acute biliary tract obstructions. The ALT is usually more frequently increased as compared to AST except in chronic liver disease. In uncomplicated acute viral hepatitis, the very high initial levels approach normal levels within 5 weeks of onset of illness and normal levels are obtained in 8 weeks in $75 \%$ of cases. For reasons, which are not understood AST levels appear disproportionately low in patients with Wilson disease (Friedman et al, 2003)

3. Mild (1-3 times): These elevations are usually seen in sepsis induced neonatal 
hepatitis, extrahepatic biliary atresia (EHBA), fatty liver, cirrhosis, non-alcoholic steatohepatitis (NASH), drug toxicity, myositis and even after vigorous exercise (Daniel and Marshall, 1999). One third to one half of healthy individuals with an isolated elevation of ALT on repeated testing have been found to be normal (Katkov, 1991).

\section{Other enzyme tests of hepatocellular necrosis}

None of these tests have proved to be useful in practice than the aminotransferases. These include glutamate dehydrogenase, isocitrate dehydrogenase, lactate dehydrogenase and sorbitol dehydrogenase

\subsection{MATERIALS}

$>$ Aqueous leaf extract of Anacardium occidentale

$>\quad 25$ male Wistar rats

$>$ Formalin

$>\quad$ Dissecting board

$>\quad$ Paracetamol (Emzor pharmaceutical industrial

Ltd.)

$>\quad$ Standard plastic cage

$>$ Electronic weighing balance (NAPCO

Precision instrument JA-410)

$>\quad$ Distilled water

$>\quad$ Syringes

$>\quad$ Oral cannula

$>\quad$ Grower feed (Top vital feed)

$>\quad$ Refrigerator

$>\quad$ Animal weighing balance

$>$ Saw dust

$>\quad$ Mechanical grinder

$>\quad$ Hand gloves
$>$ Filter paper (no.1 WATTMAN FILTER PAPER)

\subsection{LOCATION OF STUDY}

This project was carried out at the Animal House of the Faculty of Basic Medical Sciences, College of Health Sciences, Nnamdi Azikiwe University, Nnewi Campus, Anambra State.

\subsection{EXPERIMENTAL ANIMALS}

A total of twenty (25) adult male Wistar rats weighing $100 \mathrm{~g}-200 \mathrm{~g}$ were used for this study. They were kept in standard cages and housed at standard room temperature and relative humidity. The animals were fed with rat grower feeds and allowed to drink water ad libitum. They were acclimatized for two weeks before the commencement of the experiment.

\subsection{COLLECTION AND PREPARATION OF PLANT EXTRACT}

Large quantity of Anacardium occidentale leaves were harvested freshly from King's lodge, Okofia, Otolo Nnewi.

They were then washed free of dust and dried under mild sunlight and then ground with a mechanical grinder. The powder was then sieved and dissolved in 2 litres of distilled water and kept for 48 hours, after which it was filtered using filter paper. The extract was concentrated and further dried into a gel-like form using hot air oven at $50^{\circ} \mathrm{C}$. The extract was then stored in the refrigerator at $4{ }^{\circ} \mathrm{C}$.

\subsection{PROCUREMENT OF DRUG}

Paracetamol was purchased from Christ De King pharmaceutical company Ltd, Nnewi, Anambra state.

\subsection{EXPERIMENTAL DESIGN}

The animals were divided into 5 groups of 5 rats. $1000 \mathrm{mg} / \mathrm{kg}$ of paracetamol was given for 3 days to induce liver damage in groups B-E. GROUP A served as the normal control group and received feed and water

GROUP B served as negative control group and received feeds and water but not treated GROUP C received $150 \mathrm{mg} / \mathrm{kg}$ of extract of Anacardium occidentale for 21 days. GROUP D received $300 \mathrm{mg} / \mathrm{kg}$ of extract of Anacardium occidentale for 21 days. GROUP E received $500 \mathrm{mg} / \mathrm{kg}$ of extract of Anacardium occidentale for 21 days.

For the calculation of dosage, the formula below was used:

Calculated injection volume $(\mathrm{ml})=\underline{\text { mean }} \underline{\text { weight of }}$ animals $(\mathrm{kg})$ x Dose $(\mathrm{mg} / \mathrm{kg})$

Concentration $(\mathrm{mg} / \mathrm{ml})$

\subsection{MEASUREMENT OF BODY WEIGHT}

Body weight was measured before and after the administration of paracetamol and leaf extract of Anacardium occidentale using the animal weighing balance, manufactured by Camry (Model: J11063759). 


\subsection{ACUTE TOXICITY/LD50}

The lethal dose (LD50) of paracetamol (acetaminophen) was found to be $2402 \mathrm{mg} / \mathrm{kg}$ for rats, through the oral route (Pfizer, 2014). A research carried out by Koran et al, 2007 showed that the crude extract did not produce toxic symptoms in rats in doses up to $2000 \mathrm{mg} / \mathrm{kg}$.

\subsection{COLLECTION/ PROCESSING OF SAMPLES}

After the 21 days of administration of the extract, the rats were sacrificed. Blood samples were collected for determination of serum levels of liver enzymes, ALT and AST.

\subsection{STATISTICAL ANALYSIS}

All data obtained were subjected to statistical analysis using t-test, one-way ANOVA and POST HOC LSD using SPSS for windows, version 20. Differences between means were regarded significant at $\mathrm{P}<0.05$. Data were expressed as mean + standard error of mean (SEM).

\subsection{RESULTS}

Data obtained were subjected to statistical analysis using T-test, one-way ANOVA and POST HOC LSD using SPSS for windows, version 20. Differences between means were regarded significant at $\mathrm{P}<0.05$. Data were expressed as mean \pm standard error of mean (SEM).

Table 4.1 shows a statistical difference in the levels of the liver enzymes AST and ALT, in Group B and the treated groups when compared to Group A. Across the test groups, there was a significant increase $(\mathrm{P}<0.05)$ with increasing dose of the leaf extract.

Table 4.1: Effects of the aqueous leaf extract of Anacardium occidentale

on the liver enzymes AST and ALT in Paracetamol-induced hepatotoxicity

\begin{tabular}{|c|c|c|c|c|c|}
\hline 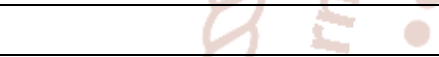 & & Mean \pm & SEM & P-VALUE & F-VALUE \\
\hline \multirow{5}{*}{$\begin{array}{c}\text { ASPARTATE } \\
\text { AMINOTRANSFERASE }\end{array}$} & GROUP A & $15.66 \pm$ & 0.33 & $\mathrm{C}$ & \multirow{5}{*}{5.262} \\
\hline & GROUP B & $17.66 \pm$ & 0.88 & 0.421 & \\
\hline & GROUP C & $16.33 \pm$ & 1.76 & 0.786 & \\
\hline & GROUP D & $18.66 \pm$ & 1.33 & 0.237 & \\
\hline & GROUP E & $25.33 \pm$ & 2.91 & $0.002 *$ & \\
\hline \multirow{6}{*}{$\begin{array}{c}\text { ALANINE } \\
\text { AMINOTRANSFERASE }\end{array}$} & 8 & & & 0 & \multirow{6}{*}{12.058} \\
\hline & GROUP A & $12.33 \pm$ & 0.33 & 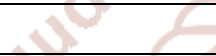 & \\
\hline & GROUP B & $15.66 \pm$ & 0.33 & 0.102 & \\
\hline & GROUP C & $14.66 \pm$ & 0.88 & 0.236 & \\
\hline & GROUP D & $16.66 \pm$ & 1.85 & $0.041^{*}$ & \\
\hline & GROUP E & $24.33 \pm$ & 2.03 & $0.000 *$ & \\
\hline
\end{tabular}

The table shows an increase in the mean values for AST in Group B (17.6667 \pm 0.8819$)$, Group D (18.6667 \pm $1.3333)$ and Group E $(25.3333 \pm 2.9059)$ when compared to Group A (15.666 \pm 0.3333$)$.

Also, there is an increase in the mean values for ALT in Group B (15.6667 \pm 0.3333$)$, Group D (16.6667 \pm $1.8559)$ and Group E $(24.3333 \pm 2.02759)$, when compared to Group A (12.3333 \pm 0.3333$)$. 
International Journal of Trend in Scientific Research and Development (IJTSRD) ISSN: 2456-6470

Table 4.2: Effect of aqueous leaf extract of anacardium occidentale on body weight in Paracetamol-induced hepatotoxicity

\begin{tabular}{|cl|c|c|c|c|}
\hline \multicolumn{2}{|c|}{$\begin{array}{l}\text { ANIMAL } \\
\text { GROUPS }\end{array}$} & \multicolumn{2}{c|}{ Mean \pm SEM } & \multicolumn{2}{c|}{ significance T-value } \\
\hline \multirow{2}{*}{ GROUP A } & INITIAL WEIGHT & 106.66 & \pm 3.33 & $0.010^{*}$ & -12.500 \\
& FINAL WEIGHT & 190.00 & \pm 5.77 & & \\
\hline \multirow{2}{*}{ GROUP B } & INITIAL WEIGHT & 200.00 & \pm 11.54 & 0.221 & 1.549 \\
& FINAL WEIGHT & 180.00 & \pm 5.77 & & \\
\hline \multirow{2}{*}{ GROUP C } & INITIAL WEIGHT & 140.00 & \pm 0.00 & $0.038^{*}$ & 5.000 \\
& FINAL WEIGHT & 123.33 & \pm 3.33 & & \\
\hline \multirow{2}{*}{ GROUP D } & INITIAL WEIGHT & 160.00 & \pm 0.00 & $0.020^{*}$ & \\
& FINAL WEIGHT & 136.66 & \pm 3.33 & & 11.000 \\
\hline \multirow{2}{*}{ GROUP E } & INITIAL WEIGHT & 180.00 & \pm 0.00 & $0.008^{*}$ & \\
& FINAL WEIGHT & 143.33 & \pm 3.33 & 0 & \\
\hline
\end{tabular}

Data were analyzed using Student Dependent T-test and values were considered significant at $\mathrm{P}<0.05$.

Result from the table above showed a significant increase in body weight in Group A and a significant decrease in Groups C, D and E, when comparing the initial weights to the final weights.

Table 4.3: Effect of aqueous leaf extract of anacardium occidentale on liver weight in Paracetamol-induced hepatotoxicity

\begin{tabular}{|c|c|c|c|}
\hline & Mean \pm SEM & P-VALUE & F-VALUE \\
\hline GROUP A & $5.58 \pm 0.30$ & & \\
\hline GROUP B & $4.59 \pm 0.17$ & $0.009 *$ & \\
\hline GROUP C & $5.73 \pm 0.22$ & 0.631 & \\
\hline GROUP D & $5.24 \pm 0.22$ & 0.292 & \\
\hline GROUP E & $4.34 \pm 0.18$ & $0.002 *$ & \\
\hline
\end{tabular}

Data obtained were subjected to statistical analysis using one-way ANOVA and differences between means were regarded significant at $\mathrm{P}<0.05$.

Results from the table shows a significant decrease in the weight of the liver for Group B $(4.59 \pm 0.17)$ and Group E $(4.34 \pm 0.18)$ when compared to Group A $(5.58 \pm 0.30)$. there were also changes in the liver weights for groups $\mathrm{C}$ and $\mathrm{D}$, though they are considered to be statistically insignificant.

\subsection{DISCUSSION}

Paracetamol is a widely used medication which has a good safety profile, although large doses may lead to severe hepatic necrosis and fatal hepatic failure (Lesko and Mitchell, 1999). According to recent information provided by the American National Poison Data System (NPDS), paracetamol is one of the 25 drugs associated with the largest number of fatalities, either alone or in combination with other medications (Mowry et al, 2015). Despite the widespread use, few scientific studies have been 
undertaken to ascertain the safety and efficacy of traditional+ remedies. To confirm the toxic nature of any plant product, one has to consider se+veral factors that can alter its toxicity profile, including the growth stage, and the maturity of the plant, the specific part(s) of the plants (such as leaves, roots, bark, flowers, seeds etc) used, the storage conditions of the product (freshly collected or stored for long time) the seasonal variation in the relative abundance of phytochemicals (Jaouad et al, 2004).

The results of this experiment showed a relationship between paracetamol and increase in serum AST and ALT. Results from table 4.1 shows an increase in AST and ALT in Groups B, D and E when compared to group A. However, group $\mathrm{C}$ showed a decrease when compared to group B. This can be attributed to the relative toxicity of the extract administered which showed a little remedying effect when administered in small dose but becomes more toxic in high doses. The toxic activity of Anacardium occidentale leaf extract may be related to its alkaloid content. Importantly, more than 350 species which contain alkaloids have been shown to display a wide spectrum of toxicological activities (Pageaux and Larrey, 2003). Although there are insufficient works done on the aqueous leaf extract of Anacardium occidentale specifically on the liver to support this, it is however in line with the work done by Tedong et al, (2007), who carried out a research on acute and sub-chronic toxicity of anacardium occidentale (anacardiaceae) leaves hexane extract in mice. The results from their study showed that administration of the hexane extract at doses of 10 and $14 \mathrm{~g} / \mathrm{kg}$ during 56 days resulted in significant decrease in body weight compared to the controls. Since there were significant changes in the levels of transaminases (ALT, AST) at a dose of $14 \mathrm{~g} / \mathrm{kg}$ which are good indicators of liver functions, they deduced that the Anacardium occidentale hexane extract induce damage to the liver.

Table 4.2 and 4.3 show a continuous decrease in body and liver weight across the groups with increase dosage of the extract. This can be linked to the total cholesterol and triglycerides reducing ability of the extract by antioxidant phytoconstituents of the leaves which include some vitamins and minerals. Anacardium occidentale leaves contain $33.52 \%$ to $46.26 \%$ of dietary fiber which reduces low-density lipoprotein (LDL), also referred to as the "bad" cholesterol. This is in line with the work done by Olaniyan, (2016) on Cholesterol Lowering Effect of Cashew Leaf (Anacardium occidentale) Extract on
Egg Yolk Induced Hypercholesterolaemic Rabbits. Results from their research showed a significant decrease in plasma Total cholesterol and Total triglycerides in the rabbits given $400 \mathrm{mg} / \mathrm{Kg}$ of either ethanolic or aqueous extract of Anacardium occidentale extract after they were being given $20 \%$ of powdered egg yolk of the total meal weight plus water for seven days. Dietary fiber may act on each phase of ingestion, digestion, absorption and excretion to affect cholesterol metabolism.

\subsection{CONCLUSION}

This research shows that aqueous leaf extract of Anacardium occidentale might have a little correction effect on Paracetamol induced hepatotoxicity in small doses. However, it can exert a toxic effect on the liver with increased dosage.

\section{REFERENCES}

1. Abdel M, Sherif R, Bloomston M (2010) "Liver Anatomy" Surgical clinics of North America 90(4):643-53

2. Abiaka C, Al-Awadi F, Al-Sayer H, Gulshan S, Behbehani A, Farghally M, Simbeye A. (2001) "Serum antioxidant and cholesterol levels in patients with different types of cancer". J Clin Lab Anal. 15(6):324-30.

3. Abulude F, Ogunkoya M, Akinjagunla Y (2010) "Phytochemical screening of leaves and stem of Cashew tree (Anacardiumoccidentate)". Environ Agric Food Chem, 9:815-819.

4. Agedah C, Bawo D, Nyananyo B (2010). "Identification of antimicrobial properties of cashew, Anacardium occidentale L. (Family Anacardiaceae)". Journal of Applied Science and Environmental Management, 14(3):25- 27.

5. Ajileye OO, Obuotor EM, Akinkunmi EO, Aderogba MA. Isolation and characterization of antioxidant and antimicrobial compounds from Anacardium occidentale L. (Anacardiaceae) leaf extract. J King Saud Univ Sci, 2015; 27: 244-252.

6. Akash P, Dahake P, Vishal D, Joshi A, Joshi B (2009). "Antimicrobial screening of different extract of Anacardium occidentale Linn. Leaves". Int J Chem Tech Res, 1(4):856-858.

7. Akinpelu D (2001). "Antimicrobial activity of Anacardium occidentale bark". Filoterapia, 72(3):286-287

8. Andarwulan N, Kurniasih D, Apriady RA, Rahmat H, Roto AV, Bolling BW (2012) "Polyphenols, carotenoids, and ascorbic acid in 
underutilized medicinal vegetables" J Funct Food 4: 339-347.

9. Biswas K, Kumar A, Babaria B, Prabhu K, Ramachandra S (2010). "Hepatoprotective effect of leaves of Peltophorum pterocarpum against paracetamol induced acute liver damage in rats". Journal of Basic Clinical Pharmacology; 1:10-5.

10. Boyde TRC, Latner AL (1961). "Starch gel electrophoresis of transaminases in human tissues extracts and serum". Biochemistry Journal; 82: $52-57$.

11. Chan E, Shigeyuki B, Hung T, Mami K, Tomomi I, Siu K (2017) "Ulam herbs: A review on the medicinal properties of Anacardium occidentale and Barringtonia racemose" Journal of Applied Pharmaceutical Science Vol. 7 (02), pp. 241-247, February, 2017 Available online at DOI: 10.7324/JAPS.2017.70235

12. Chen S, Chung K. (2000) "Mutagenicity and antimutagenicity studies of tannic acid and its related compounds". Food Chem Toxicol 38:1-5.

13. Chu J, Sadler, Kirsten C (2009). "New school in liver development: lessons from zebra fish" Hepatology 50(5):1656-63

14. Clark JM, Diehl AM (2003). "Nonalcoholic fatty liver disease: an underrecognized cause of cryptogenic cirrhosis". JAMA. 289 (22): 3000-4. doi:10.1001/jama.289.22.3000.

15. Correa M (1978). "Dicionário de plantas úteis do Brasil. Ministério da Agricultura". Rio de Janeiro: $I B D F$;. p. 55 [in Portuguese].

16. Cotran, Ramzi S, Kumar V, Fausto N, Robbins S, Abbas A (2005) "Robbins and Cotran pathologic basis of disease ( $7^{\text {th }}$ edition)" St. Louis MO Elsevier Saunders P. 878

17. Da Silva R, Liberio S, do Amaral F, do Nascimento F, Torres L, Neto V, Guerra R (2016). "Antimicrobial and antioxidant activity of Anacardium occidentale L. flowers in comparison to bark and leaves". J Biosci Med 4: 87-99.

18. Daniel SP, Marshall MK (1999). "Evaluation of the liver: laboratory tests. Schiff's diseases of the liver", 8th edn. USA; JB Lippincott publications, 1999; 205-239.

19. Dare S, Hamman W, Musa S, Goji A, Oyewale A, Abba S (2011) "Effects of aqueous extract of Anacardium occidentale (cashew) leaf on pregnancy outcome of wistar rats ". Int J Anim Vet Adv 3:77-82.

20. De Giorgio F, Lodise M, Chiarotti M, d'Aloja E, Carbone A, Valerio L (2013) "Possible fatal acetaminophen intoxication with atypical clinical presentation". Journal of Forensic Science 58: 1397-1400.

21. Del R, Tewart A, Pellegrini N (2005) “A review of recent studies on malondialdehyde as toxic molecule and biological marker of oxidative stress." Nutr Metab Cardiovasc Dis, 15: 316-328.

22. Derry S, Moore RA (2013) "Paracetamol (acetaminophen) with or without an antiemetic for acute migraine headaches in adults" Cochrane Database Syst Rev4. Doyon S, Klein-Schwartz W, Lee S, Beuhler MC. (2013) "Fatalities

involving acetaminophen combination products reported to United States poison centers". Clinical Toxicology 51: 941-948.

23. Duarte J, Perez-Palencia R, Vargas F, Ocete MA, Perez-Vizcaino F, Zarzuelo A, Tamargo J (2001). "Anti-hypertensive effects of the flavonoid quercetin in spontaneously hypertensive rats." British Journal of Pharmacology, 133: 117-124.

24. Esimone C, Okonta J, Ezugwu C. (2001) "Blood sugar lowering effect of Anacardium occidentale leaf extract in experimental rabbit model ". J Nat Remed,; 1: 60-63.

25. Fagbohun T, Odufuwa K (2010). "Hypoglycemic effect of methanolic extract of Anacardium occidentale leaves in alloxan-induced diabetic rats." Nigerian Journal of Physiological Science 25: 87-90.

26. Fazali F, Zulkhairi A, Nurhaizan M, Kamal N, Zamree M, Shahidan M (2011). "Phytochemical Screening, in vitro and in vivo Antioxidant Activities of Aqueous Extract of Anacardium occidentale Linn. and its Effects on Endogenous Antioxidant Enzymes in Hypercholesterolemic Induced Rabbits”. Research Journal of Biological Sciences. 6(2):69-74.

27. Fortuny J, Kogevinas M, Real F, Tardon A, Serra C, Carrato A, Rothman N, Villanueva C, Dosemeci M, Malats, N, Silverman D (2006). "Use of analgesics and non-steroidal antiinflammatory drugs, genetic predisposition and bladder cancer risk in spain". Cancer epidermiology, Biomarkers and prevention 15(9):1696-1702

28. França F, Cuba C, Moreira E, Miguel O, Almeida M, das Virgens M, (1993). "An evaluation of the effect of a bark extract from the cashew (Anacardium occidentale L.) on infection by Leishmania (Viannia) braziliensis." Rev Soc Bras Med Trop; 26:151-5.

29. Franca F, Lago E, Marsden P, (1996). "Plants used in the treatment of leishmanial ulcers due to 
International Journal of Trend in Scientific Research and Development (IJTSRD) ISSN: 2456-6470

Leishmania (Viannia) braziliensis in an endemic area of Bahia, Brazil". Rev Soc Bras Med Trop, 29(3):229- 232.

30. Friedman S, Martin P, Munoz J (2003) 'Laboratory evaluation of the patient with liver disease" Hepatology, a textbook of liver disease. Philedelphia; Saunders publication; 1: 661-709.

31. Gonçalves J, Lopes R, Oliveira D, Costa S, Miranda M, Romanos M (2005) "In vitro antirotavirus activity of some medicinal plants used in Brazil against diarrhea." Journal of Ethnopharmacology 14; 99:403-7.

32. Green RM, Flamm S. (2002) "AGA technical review of evaluation of liver chemistry tests". Gastroenterology 123: 1367-1384.

33. Hammed, L, Anikwe, J. and Adedeji, A (2008). "Cashew nuts production in Nigeria." AmericanEurasian Journal of Scientific Research 3(1): 5461.

34. Haussinger D (2011) "liver regeneration" Berlin: De Gruyter p. 1

35. Herndon C, Dankenbring D (2014). "Patient perception and knowledge of acetaminophen in a large family medicine service". J Pain Palliat Care Pharmacother; 28:109-116. doi: 10.3109/15360288.2014.908993.

36. Hochhauser D (2014) "Cancer and its management" John wiley and sons p.199

37. Ifesan B, Fashakin F, Ebosele F, Oyerinde A, (2013). "Antioxidant and antimicrobial properties of selected plant leaves". Eur J Med Plant, 3(3):465-473.

38. Ikyembe D, Coston P, Abel N (2014) "Hepatoprotective Effect of Methanolic Leaf Extract of Anacardium occidentale (Cashew) on Carbon-Tetrachloride-Induced Liver Toxicity in Wistar Rats" Sub-Saharan African Journal of Medicine 1:3 [Downloaded free from http://www.ssajm.org on Monday, July 10, 2017, IP: 197.210.227.162

39. Jaeschke H, McGill M, Ramachandran A (2012). "Oxidant stress, mitochondria, and cell death mechanisms in drug-induced liver injury: lessons learned from acetaminophen hepatotoxicity". Drug Metab Rev 44:88-106. doi: 10.3109/03602532.2011.602688.

40. Jaeschke H, McGill M. (2015) “Cytochrome P450-derived versus mitochondrial oxidant stress in acetaminophen hepatotoxicity". Toxicol Lett 235: 216-217.doi: 10.1016/j.toxlet.2015.04.002.

41. Jaiswal Y, Tatke P, Gabhe S, Vaidya A (2010). "Antioxidant activity of various extracts of leaves of Anacardium Occidentale (cashew)". Res J Pharm Biol Chem Sci; 1:112-9.

42. Jaiswal Y, Tatke P, Gabhe S, Vaidya A (2016) "Antidiabetic activity of extracts of Anacardium occidentale Linn. Leaves on n-streptozotocin diabetic rats" Journal of Traditional and Complementary Medicine http://dx.doi.org/10.1016/j.jtcme.2016.11.007

43. Jaouad E, Israilli Z, Lyoussi B (2004). "Acute toxicity and chronic toxicological studies of Ajuga iva in experimental animals". Journal of Ethnopharmacology, 91: 43-50.

44. Jelkmann W (2001) "The role of the liver in the production of thrombopoietin compared with erythropoietin" European Journal of Gastroenterology and Hepatology 13(7):791-801

45. Johnston D (1999) "Special considerations in interpreting liver function tests" Am Fam Physician 59(8):2223-30

46. Kamtchouing P, Sokeng D, Moundipa P, Pierre W, Jatsa B, Lontsi D (1998). "Protective role of Anacardium occidentale extract against streptozotocin-induced diabetes in rats". Journal of Ethnopharmacology 62: 95-99.

47. Karwoski CB (2002). "Briefing Document: Acetaminophen containing products and hepatotoxicity”. Division of Drug Risk Evaluation

48. Katkov WN, Friedman LS, Cody H (1991). "Elevated serum alanine aminotransferases levels in blood donors; the contribution of hepatitis $\mathrm{C}$ virus". Ann Intern Med 115: 882-887.

49. Khoo N, White C, Pozzo-Miller L, Zhou F, Constance C, Inoue T, Parks D (2010). "Dietary flavonoid quercetin stimulates vasorelaxation in aortic vessels". Free Radical Biol Med, 49: 339347.

50. Konan N, Bacchi E (2007). "Antiulcerogenic effect and acute toxicity of hydro-ethanolic extract from the cashew (Anacardium occidentale L.) leaves". Journal of Ethnopharmacology, 112: 237-242

51. Kongkachuichai R, Charoensiri R, Yakoh K, Kringkasemsee A, Insung P (2015) "Nutrients value and antioxidant content of indigenous vegetables from Southern Thailand". Food Chem, 173: 838-846.

52. Koran NA, Marianne EB, Lincopan N, Varela SD, Varanda EA (2007). "Acute, Subacute toxicity, genotoxic effect of a hydroethanolic extract of the cashew (Anacardium OccidentaleL.)" Journal of Ethnopharmacology, 110(1): 30-38. 
53. Lancaster E, Hiatt J, Zarrinpar A (2015). "Acetaminophen hepatotoxicity: an update review”. Arch Toxicol 2015; 89: 193-199.

54. Larson J, Symons D, Jalili T (2012). “Therapeutic potential of quercetin to decrease blood pressure: Review of efficacy and mechanisms". Adv Nutr 3: 39-46.

55. Laurens AC (1999). "Screening of some medicinal plants for antimicrobial activity". Journal of Ethnopharmacology, 67(2): 225-228.

56. Léonard T, Paul D, Théophile D, Emmanuel A, Selestin N, Jean-François F, Patrice C, Pierre K (2007) "Acute and subchronic toxicity of anacardium occidentale linn (anacardiaceae) leaves hexane extract in mice". Afr. J. Trad. CAM 4 (2): $140-147$

57. Lesko SM, Mitchell AA (1999) "The safety of acetaminophen and ibuprofen among children younger than two years old". Pediatrics 104:e39.

58. Lewis J, Stine J (2009) "Review article: prescribing medications in patients with cirrshosis- a practical guide" Alimentary pharmacology and therapeutics 37(12)1132-56

59. Liu Z, Govindarajan S, Kaplowitz N (2004). "Innate immune system plays a critical role in determining the progression and severity of acetaminophen hepatotoxicity". Gastroenterology; 127:1760-1774. doi: 10.1053/j.gastro. 2004.08.053.

60. Mackeen M, Ali A, El-Sharkawy S, Manap M, Salleh K, Lajis N, Kawazu K (1997). "Antimicrobial and cytotoxic properties of some Malaysian traditional vegetables (ulam)". Pharm Biol; 35: 174-178.

61. Maia JGS, Andrade EHA, Zoghbi MGB. Volatile constituents of the leaves, fruits and flowers of cashew (Anacardium occidentale L.). J Food Compos Anal, 2000; 13: 227-232.

62. Manasa M, Kambar Y, Swamy H, Vivek M, Kumar T, Kekuda T (2013). "Antibacterial efficacy of Pimenta dioica (L.) Merill and Anacardium occidentale L. against drug resistant urinary tract pathogens". Journal of Applied Pharmacological Science; 3: 72-74.

63. McGill M, Jaeschke H (2013). "Metabolism and disposition of acetaminophen: recent advances in relation to hepatotoxicity and diagnosis". Pharmacological Research;30 2174-2187. doi: 10.1007/s11095-013-1007-6.

64. Mendes N, De Oliveira A, Guimareas J, Pereira J, Katz N (1990). "Molluscacide activity of mixture of 6-n-alkyl salicyclic acids (anacardic acid) and 2 of its complexes with coper (II) and lead (II)" Rev Soc Bras Med Trop., 23(3): 217-224.

65. Mota M, Thomas G, Barbosa Filho J (1985). "Anti-inflammatory actions of tannins isolated from the bark of Anacardium occidentale L". Journal of Ethnopharmacology; 13:289-300.

66. Mowry J, Spyker D, Brooks D, McMill N, Schauben J (2014) "Annual Report of the American Association of Poison Control Centers' National Poison Data System (NPDS): 32nd

AnnualReport”. Clinical Toxicology 2015; 53: 962-1147

67. Muriel P, Garciapiña T, Perez V, Mourelle M. (1992) "Silymarin protects against paracetamolinduced lipid peroxidation and liver damage". Journal Applied Toxicology; 12:439-42.

\section{Nalpus B, Vassault A, Charpin}

S (1986) "Serum mitochondrial aspartate amonitransferase as a marker of chronic alcoholism: diagnostic value and interpretation in a liver unit”. Hepatology; 6: 608-613.

69. Nor Ayshah Alia A, Mohd Shukri M, Razali M. (2016) "Antimicrobial potency of essential oil from cashew (Anacardium occidentale Linn.) clones". Journal of Tropical Agricultural Food Science; 44: 73-80.

70. Nugroho A, Malik A, Pramono S (2013). "Total phenolic and flavonoid contents and in vitro antihypertension activity of purified extract of Indonesian cashew leaves (Anacardium occidentale L.)"'. International Food Research Journal; 20: 299-305.

71. Nyblom H, Bjornsson E, Simren M, Aldenborg F, Almer S, Olsson R (2006) "The AST/ALT ratio as an indicator of cirrhosis in patients with $\mathrm{PBC}$ " Liver int 26(7):840-845

72. Ogunsina, B \& Lucas, E (2008). "Development of a manually operated cashew juice extractor Agricultural Engineering International": African crop science Journal 3(2).

73. Ojewole JA (2003). "Laboratory evaluation of the hypoglycemic effect of Anacardium occidentale Linn. (Anacardiaceae) stem-bark extracts in rats". Methods Find Exp Clin Pharmacol 25:199-204.

74. Ojewole JA (2004). "Potentiation of the antiinflammatory effect of Anacardium occidentale (Linn) stem-bark extract by grapefruit juice". Methods Find Exp Journal of Clinical Pharmacology., 26: 183-188.

75. Okwu D, Okwu M (2004) "Chemical composition of Spondias mombin linn plant parts". J Sustainable Agriculture Environment 6: 140-147. 
76. Olaniyan M (2016) "Cholesterol Lowering Effect of Cashew Leaf (Anacardium occidentale) Extract on Egg Yolk Induced Hypercholesterolaemic Rabbits" Scholars Academic Journal of Biosciences ISSN 2321-6883 (Online)4(10B):886$891 \quad$ DOI: $10.21276 /$ sajb.2016.4.10.16

77. Omoboyowa D (2011) "Activity of chloroformethanol extracts of cashew (anacardium occidentale) kernel in castor oil-induced diarrhoea in rats"

78. Omojasola P, Awe S, (2004). "The antibacterial activity of the leaf extracts of Anacardium occidentale and Gossypium

79. hirsutun against some selected microorganisms". Biosci Res Commun, 60(1):25-58.

80. Onasanwo S, Fabiyi T, Oluwole F, Olaleye S. (2012) "Analgesic and anti-inflammatory properties of the leaf extracts of Anacardium occidentale in the laboratory rodents". Nigerian Journal of Physiological Science 27: 65-71.

81. Orwa C, Mutua A, Kindt R, Jamnadass R, Simons A, (2009). "Agroforest tree Database: A tree reference and selection guide version" 4.0 (http://www.worldagroforestry.org/af/treedb/).

82. Pageaux G, Larrey D (2003) "Alternative medicine, vitamins and natural hepatotoxins in Drug-Induced liver disease". Kaplowitz N and Deleve LD, Eds. Marcel Dekker, New York, Basel.

83. Palanivel M, Rajkapoor B, Senthil K, Einstein J, Kumar E, Rupesh K (2008) "Hepatoprotective and antioxidant effect of Pisonia aculeata 1. Against CCl4-induced hepatic damage in rats" Sci Pharm;76:203-15.

84. Patrick R, Murray K, Rosenthal M, Pfaller A, (2013). "Medicalmicrobiology (7th ed). St Louis, Mo. Mosby". P, 418

85. Pawar S, Pal S (2002). "Analgesic and antiinflammatory activity of Anacardium occidentale root extracts". Hamdard-Medicus, 45(4):63-68.

86. Pawar S, Sathwane P, Metkar B, Pal S, Kasture V, Kasture S. (2000) "Anti-inflammatory and analgesic activity of Anacardium occidentale leaf extracts." Ancient Science of Life; 19: 169-173.

87. Perrot D, Piira T, Goodenough B, Champion G (2004) "Efficacy and safety of acetaminophen vs ibuprofen for treating children's pain or fever: a meta-analysis" Arch Pediatr Adolesc Med 158(6): 521-6

88. Perz J, Armstrong G, Farrington L, Hutin Y, Bell B. (2006) "The contributions of hepatitis B virus and hepatitis $\mathrm{C}$ virus infections to cirrhosis and primary liver cancer worldwide". Journal of Hepatology 45:529-38.

89. Prakash T, Fadadu S, Sharma U, Surendra V, Goli D, Stamina P (2008) "Hepatoprotective activity of leaves of Rhododendron arboreum in $\mathrm{CCl} 4$ induced hepatotoxicity in rats." Journal of Medicinal Plants Research; 2:315-20.

90. Premalatha B, Sachdanandam P (1996). "Semecarpus anacardium L. nut extract administration induces the in vivo antioxidant defence system in aflatoxin B1 mediated hepatocellular carcinoma". Journal of Ethnopharmacology; 66:131-9.

91. Proceedings of the FDA NDAC meeting, September 19, 2002. Testimony of Parivash Nourjah, Ph.D. Available at:

www.fda.gov/ohrms/dockets/ac/cder02.htm\#Nonp rescriptionDrugs [Last access on $7^{\text {th }}$ December 2017].

92. Proudfoot AT, Wright N (1970) "Acute paracetamol poisoning". British Medical Journey 3:557-8.

93. Razalia N, Razaba R, Junita S, Aziz A, (2008). "Radical scavenging and reducing properties of extracts of cashew shoots (Anacardium occidentale)". Food Chem, 111:38-44.

94. Rej R. (1985) "Measurement of aminotransferases, aspartate aminotransferases. CRC Crit Rev" Clin Lab Sci 21: 99-103

95. Rocha J, Gabriel, G, Posser L, Siqueira C, Noguira and Folmer V (2005) "Ebselen and diphenyl diselenide change biochemical hepatic responses to overdasage with paracetamol". Environmental and Toxicology Pharmacology 19:255-261

96. Rosalki SB, Mcintyre N (1999) "Biochemical investigations in the management of liver disease". Oxford textbook of clinical hepatology, 2nd ed. New York; Oxford university press;503521.

97. Saidu A, Mann A, Balogun S. (2012) "The hypoglycemic effect of aqueous extract of the Anacardium occidentale Linn. leaves grown in Nigeria on normoglycemic albino rats". J Emerg Trends Eng Appl Sci, 2012; 3: 302-308.

98. Sambo, Sarah H, Olatunde, Luka, Carrol D (2014) "Anti-diabetic activity of aqueous extract of anacardium Occidentale (linn) stem bark in normal and alloxan-induced Diabetic albino rats" Journal of Biological Sciences and Bioconservation 6:2 ISSN: 2277-0143 
99. Sanyal, A J (2002). "AGA Technical Review on Nonalcoholic Fatty Liver Disease.". Bethesda, MD: American Gastroenterological Association

100. Schmidt L, Dalhoff K, Poulsen H (2002). "Acute versus chronic alcohol consumption in acetaminophen-induced hepatotoxicity".
Hepatology; 35:876-

101. Sheen C, Dill J, Bateman D, Simpson J, MacDonald T (2002) "Paracetamol-related deaths in Scotland, 1994-2000". British Journal of Clinical Pharmacology; 54: 430-432.

102. Sherlock S (1997). "Assessment of liver function Disease of liver and biliary system: Sheila" Sherlock, 10th edn, London; Blackwell science ltd; 17-32.

103. Sherwood L (2010) "Human Physiology: from cells to systems $\left(7^{\text {th }}\right.$ edition)" Yolanda Cossio ISBN-13: 978-0-495-39184-5

104. Shetty P, Hegde V, Gomes L (2014). "Anticandidal efficacy of denture cleansing tablet, triphala, Aloe vera, and cashew leaf on complete dentures of institutionalized elderly". Journal of Ayurv Integrated Medicine, ;5: 11-14.

105. Shukri MAM, Alan C (2010) "Analysis of phenolics in Anacardium occidentale shoot extracts using a reversed-phase high performance liquid chromatography tandem mass spectrometry (RP-HPLC-MS)". J Trop Agric Food Sci 38: 221230.

106. Sokeng D, Kamtchouing P, Watcho P, Jatsa H, Moundipa P, Ngounou F (2001) "Hypoglycemic activity of Anacardium occidentale L. aqueous extract in normal and streptozotocininduced diabetic rats". Diabetes Res; 36:001-9.

107. Sokeng S, Kamtchouing P, Watcho P, Jatsa H, Moundipa P, Lontsi D. (2007) "Hypoglycemic effect of Anacardium occidentale L. methanol extract and fractions on streptozotocin-induced diabetic rats". Global Journal of Pharmacology; 1: $1-5$.

108. Soufy N. (2012) "Hepatoprotective and antioxidant effects of Silybum marianum plant against hepatotoxicity induced by carbon tetrachloride in rats". Journal of American Science; 8:479-786.

109. Tan Y, Chan E (2014). “Antioxidant, antityrosinase and antibacterial properties of fresh and processed leaves of Anacardium occidentale and Piper betle". Food Bioscience; 6: 17-23.

110. Tedong L, Dimo T, Dzeufiet P, Asongalem A, Sokeng D, Callard P, Flejou J, Kamtchouing P
(2006). "Anti-hyperglycemic and renalprotective activities of Anacardium occidentale leav es in streptozotocin induced diabetic rats". African Journal of Traditional and Complementary Alternative Medicine; 3: 23-35.

111. Tirkey N, Pilkhwal S, Kuhad A, Chopra K (2005) "Hesperidin, a citrus bioflavonoid, decreases the oxidative stress produced by carbon tetrachloride in rat liver and kidney. $B M C$ Pharmacol; 5:2.

112. Tortura GJ, Derrickson, Bryan H (2008) "Principles of Anatomy and Physiology (12 ${ }^{\text {th }}$ ed)" John Wiley \& sons p.945 ISBN 978-0-470-08471

113. Varghese J, Tumkur VK, Ballal V, Bhat GS, (2013). "Antimicrobial effect of Anacardium occidentale leaf extract against pathogens causing periodontal disease". Advanced journal of Bioscience and Biotechnology, 4:15-18.

114. Victor U, Olumide A, David A, Efere O, Abiola T, Abayomi B Ezekiel C (2012) "Evaluation of antioxidant potential of methanolic leaf extract of Anacardium Occidentale (Linn) on the testes of streptozotocin-induced diabetic wistar rats" European Journal of Anatomy 17 (2): 72-81

115. Weber P, Benedich A, Scalch W (1996) "Vitamin C and Human Health - A review of recent data relevant to human requirements". International Journal of Vitamin Nutrition Research, 66: 19-30. 